\title{
THE TUUPOVAARA END MORAINE IN NORTH KARELIA, EASTERN FINLAND - AN ICE-MARGINAL FORMATION OF THE SAME AGE AS THE SALPAUSSELKÄ RIDGES
}

\author{
HEIKKI RAINIO
}

\begin{abstract}
RAINIO HEIKKI, 1983: The Tuupovaara end moraine in North Karelia, Eastern Finland - an ice-marginal formation of the same age as the Salpausselkä ridges. Bull. Geol. Soc. Finland 55, 1, 67-76.

Described in this report is a previously for the most part unknown ice-marginal formation in the province of North Karelia extending from the parish of Värtsilä via Tohmajärvi and Tuupovaara to the parish of Ilomantsi. The formation is given the name Tuupovaara End Moraine. Including a few short gaps, it is 50 kilometers long, trends $\mathrm{N}-\mathrm{S}$ and $\mathrm{SSW}-\mathrm{NNE}$ and runs at distances varying between 12 and 22 kilometers from the distal flank of Salpausselkä II. The parts formed in the Baltic Ice Lake and the local ice lake of Loitimo consist mainly of glaciofluvial material, while the supra-aquatic parts, again, are composed mostly of till and are much smaller than the glaciofluvial parts.

The Tuupovaara End Moraine is slightly younger than Salpausselkä I, but distinctly older than Salpausselkä II. This indicates that the margin of the continental ice sheet did not extend during the formation of Salpausselkä I from Värtsilä to the ice-marginal formation between Kiihtelysvaara and Selkäkangas, and that the ice receded more rapidly in the Ilomantsi area than elsewhere.

The esker complex of Otmen, which is located on the east side of the Tuupovaara End Moraine at a distance of between two and five kilometers, rests on the boundary between two different sets of striations. Judged on this evidence and by its structural features, it must be identified as an interlobate complex.
\end{abstract}

Key words: ice-marginal formation, Salpausselkä, end moraines, deglaciation, Quaternary, North Karelia, Finland.

Heikki Rainio: Geological Survey of Finland, Kivimiehentie 1 SF - 02150 Espoo 15, Finland.

\section{Introduction}

In North Karelia there occurs a series of ice-marginal formations some fifty kilometers long, which has previously been de- scribed in the literature only for its southern end. It runs on the distal side of Salpausselkä II, including its northeastern continuation as described by Rainio (1972), at a distance of between 12 and 20 kilometers from 
it. It runs from Pykälävaara, in the rural municipality of Värtsilä, via Kankaankylä and Pekkula, in the parish of Tohmajärvi, along the eastern side of Loitimojärvi not far from the parish center of Tuupovaara, continuing from there in a north-northeasterly direction via Herajärvi and on the northwestern side of Perttivaara to a point close to Haapovaara, in the parish of Ilomantsi. From there it cannot be followed any farther. Judging by its situation, the end moraine originated during the formation of the Salpausselkä ridges. The conclusions that can be drawn regarding its trend and its features are of importance in solving problems connected with the deglaciation in North Karelia at the time of origin of the Salpausselkä ranges (Fig. 1).

In the following discussion of the series of ice-marginal formations, the designation 'end moraine' or 'Tuupovaara End Moraine' will be used as the need for clarity might require.

\section{Salpausselkä I}

The view has gained general acceptance that Salpausselkä I extends in the east to the vicinity of Sääperinjärvi in the municipality of Värtsilä (cf., e.g., Repo \& Tynni 1967, p. 134). The delta plain of Patsola is its most northeastern part. About its northern or northeastern extension, opinion is divided.

The prevailing trend of the ice margin indicated by the deltas located at the northeastern end of Salpausselkä I is $\mathrm{N} 30^{\circ} \mathrm{E}$ and that of the proximal slope of the delta plain of Patsola $\mathrm{N} 25^{\circ} \mathrm{E}$ - in other words, by and large north-northeasterly.

The height of the distal edge of the Musko, Kaurila and Patsola delta plains in this part of the sequence is 110 meters above sea level, as calculated from the basic maps; and this is thus the B I elevation in this region.

\section{Bedrock}

The bedrock of the area is divided geologically into two complexes: 1 - The old basement gneiss or the granite gneiss complex in the eastern part of the region. 2 - The Karelidic schists or Karelides in the western part (Nykänen 1971, p. 95).

\section{Earlier investigations}

Ramsay (1891, p. 6) noted that in the environs of Loitimojärvi there were extensive sand and till deposits, which appeared to belong to the outermost end moraine, or Salpausselkä I. By this he may have meant the ice-marginal formation described here or the large, complex eskers in the vicinity of Loitimo.

Rosberg explored the area on the northern side of Loitimojärvi on the basis of Ramsay's indications, but apparently too far to the west, for between Huhtilampi and Kluostarinvaara he found "nothing» (Rosberg 1899, pp. 31-32).

In the explanatory text accompanying the Joensuu map of Quaternary deposits, there is the statement that "on the east side of Jänisjoki in northern Tohmajärvi, there runs a $\mathrm{S}-\mathrm{N}$-trending line of eskers, which, broken at many points, must be regarded as the northernmost extension of the outermost Salpausselkä range.» The ice-marginal formation was described as terminating in a plateau, by which is evidently meant Murtojärvenkangas. The text further mentioned the eskers situated on the southeastern and northern sides of Loitimojärvi, which to some extent took on »the nature of a marginal formation.» By this was conceivably meant the series of eskers running across the end moraine in the area of the parish center of Tuupovaara. The map-makers might also have interpreted the portion of the ice-marginal formation on the east side of 


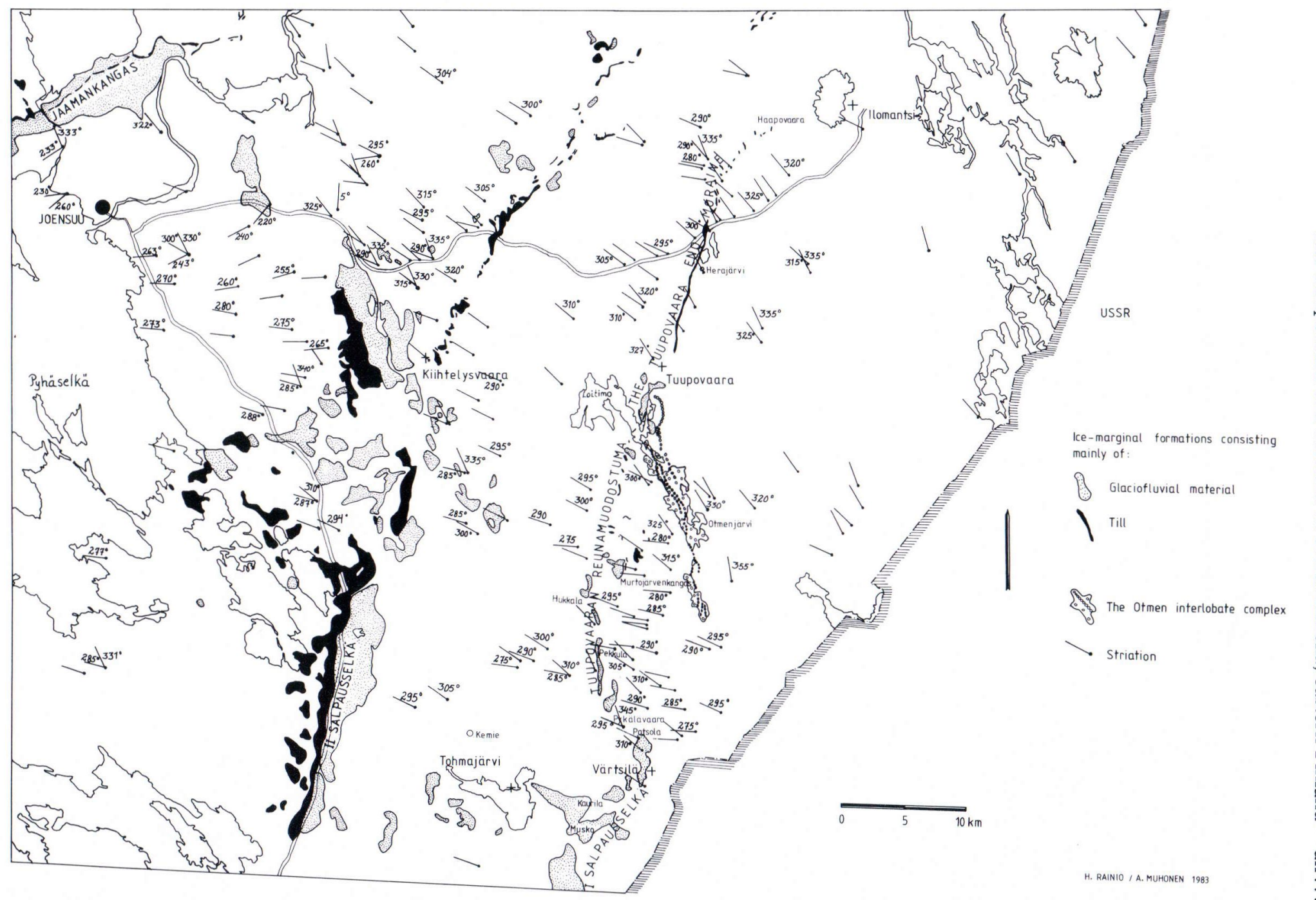

Fig. 1. Map showing the Tuupovaara End Moraine, part of the Second Salpausselkä, The Jaamankangas End Moraine, and striations. 
Loitimojärvi as belonging to this esker chain, so intricate is the complex of glacial formations in this district. (Frosterus \& Wilkman 1917, pp. 51 and 81).

Leiviskä (1920, pp. 110 and 228) also briefly mentioned the »esker chain» (Åskette) running northward on the east side of Jänisjoki to "terminate farther north in hilly terrain," where "we can see a direct continuation of the Salpausselkä.» Leiviskä also referred to the features of a »longitudinal esker.» By the esker chain he meant the southern sequence terminating in the ice-marginal delta of Pekkula or Murtojärvenkangas.

The northern part of the ice-marginal formation dealt with in this study was mentioned by Rainio in the printed guide drawn up for distribution to participants in the 1978 field excursion of NORDQUA, the society of Quaternary geologists of the Nordic countries (Rainio 1978) as well as in the field excursion guide for students enrolled in the University of Helsinki (Rainio 1980). In the sketch map appended to the latter guide (p. 13) and the one subsequently accompanying Rainio's article (1982) on the loess-covered areas of North Karelia, the icemarginal formation dealt with here can be seen in its entirety.

Salminen possibly was thinking to some extent of the subject of this study in referring to $»$ the marginal formation associated with Salpausselkä I ... which runs from Värtsilä via Tuupovaara and Kovero to Aittovaara» (Salminen 1980, p. 19). On the basis of what he set forth on the sketch map (p. 14), he probably meant by the portion on the south side of Tuupovaara also the great esker sequence mentioned in the foregoing exposition of Frosterus's and Wilkman's views. The sequence indicated by Salminen on the map between the parish center of Tuupovaara, Kovero and Aittovaara is a longitudinal esker with delta extensions. The extensions repre- sent positions of the ice margin younger than the marginal formation of Tuupovaara.

Hirvas (1980) and Ignatius et al. (1980) offer for consideration from this area - on, to be sure, small-scale maps - positions of the ice margin which call for comment here.

Although Repo's (1957) study is limited to the western part of the region covered by the present work, it is applicable here, too, as far as the movements of the continental ice sheet are concerned. Accordingly, the oldest movement of the ice in this region was from the north-northwest, and the next from the northwest or west-northwest. The last, westerly movement of the ice sheet extended as far as Salpausselkä II, possibly as the ice readvanced after a short retreat. (Repo 1957, pp. 138-143).

\section{Field investigations and elevation data}

For the present study, the entire sequence of ice-marginal formations was mapped in the field, and striae observations and 27 stone counts were made, 16 of them on the proximal side of the marginal formation, four on the formation itself and seven on its distal side. Six cross-sections were levelled in portions of the formation representing different depositional environments.

The elevations reported in this study have been taken from the basic maps.

\section{The Tuupovaara End Moraine}

At its south end, the Tuupovaara End Moraine starts from Pykälävaara, which is located about four kilometers to the NNW from the delta plain of Patsola, which belongs to Salpausselkä I. There it is roughly two kilometers long, from 200 to 800 meters wide and oriented $\mathrm{N}-\mathrm{S}$ on the southern end, forming a distinct delta plain at 110-115 meters above present sea level. 
At a distance of one kilometer on the proximal side of the Pykälävaara delta plain is another formation, the Kankaankylä ridge, running in a north-south line for a length of six kilometers. It varies in width from 100 to 400 meters and in height from a few to 25 meters. Judging by the gravel pits, it is composed mainly of glaciofluvial material, which is covered on the proximal side by a thin layer of till (Fig. 2, Cross-sections 1 and 2). It does not have the level stretches that commonly occur on glaciofluvial end moraines, except at Pekkula, where the elevation of the plateau is approximately 110 meters above sea level.

At Pekkula, the end moraine is cut for a short distance by an elevated bed-rock area, after which it continues on for a kilometer and is broken off again by supra-aquatic terrain.

The formation continues after a break of some four kilometers, on the NNE side in the shape of the plateau of Murtojärvenkangas, which rises along its length of about three kilometers to an elevation of 115 meters.

On the proximal side of the line between the Kankaankylä ridge and the Murtojärvenkangas plateau, at a distance of less than two kilometers, there is the delta plain of Hukkala (Fig. 2, Cross-section 5), which is about two kilometers long and 600-800 meters wide and which lies at an elevation of 115 meters above sea level.

In the six-kilometer supra-aquatic section between Murtojärvenkangas and Loitimojärvi, the end moraine consists of a disconnected cluster of small ridges and mounds. A short distance south of Loitimojärvi, it includes the Mustalampi delta, which covers an area of about one square kilometer. The delta is topographically exceedingly broken up, and the narrow, level summit lies at an elevation of 130 meters.

From the southern tip of Kuljunniemi, jutting out into Lake Loitimojärvi on its eastern side, the end moraine continues uninterruptedly for some five kilometers to the western side of the village of Tuupovaara. To this Kuljunniemi section belongs, on its proximal side, a marginal till ridge and, on its distal side, a marginal delta plain as much as 400 meters in width and reaching an elevation of 125-130 meters (Fig. 2, Crosssection 6).

On the east side of Kuljunniemi and Mustalampi sections, there runs, at a distance of 2-5 kilometers, in the same direction the great esker of Otmen, which also has marginal formation portions. That is what Frosterus and Wilkman (1917, pp. 81-82) probably meant when discussing the aforementioned esker (see p. 68). Somewhat to the south of the village of Tuupovaara, the esker turns northwestward and joins the end moraine a kilometer away on the west side of the village. The esker continues on the proximal side of the end moraine along the eastern shore of Lastujärvi in the NNW direction.

There is a two-kilometer break in the end moraine at the village of Tuupovaara. On the northeastern side of the village, it continues nearly without a break as a till ridge for a distance of some 13 kilometers in a northnortheasterly direction at an elevation of 145-200 meters. The southern portion of this Herajärvi section consists of a till ridge 5-10 $\mathrm{m}$ high and 30-100 $\mathrm{m}$ broad for a stretch of seven kilometers. On the isthmus between Saarijärvi and Herajärvi, it spreads out to a width of as much as 250 meters and rises to a height of between 25 and 30 meters (Fig. 2, Cross-sections 3 and 4). In places, it splits up into two parallel ridges. It continues high and broad for about four kilometers on the north side of the Ilomantsi-Joensuu highway and on smaller lines for two more kilometers.

At Herajärvi, right on the distal side of the end moraine, there rises an esker plateau to 

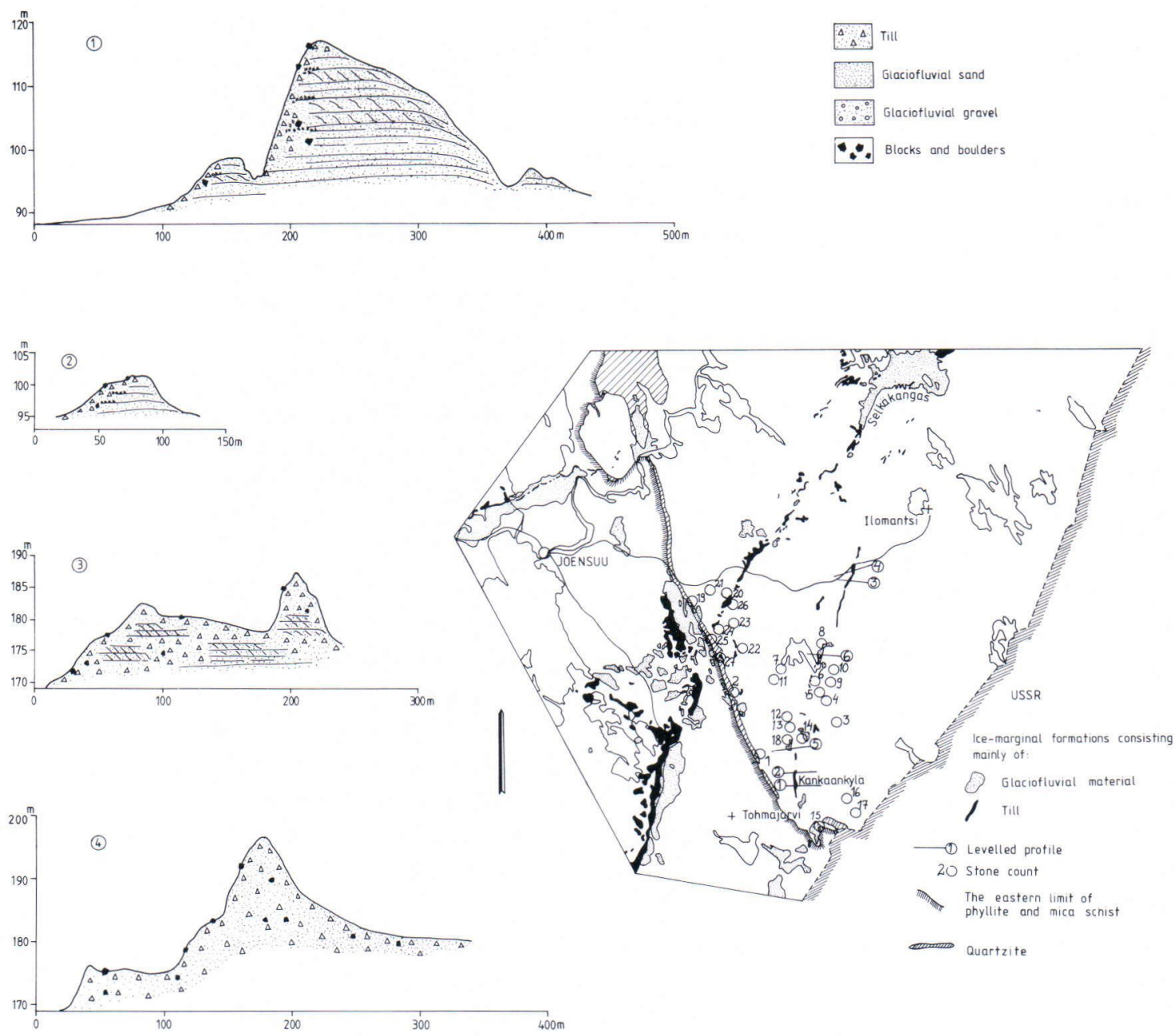

(1) Levelled protile

20 stone count

The eastern limit of

Quartzite
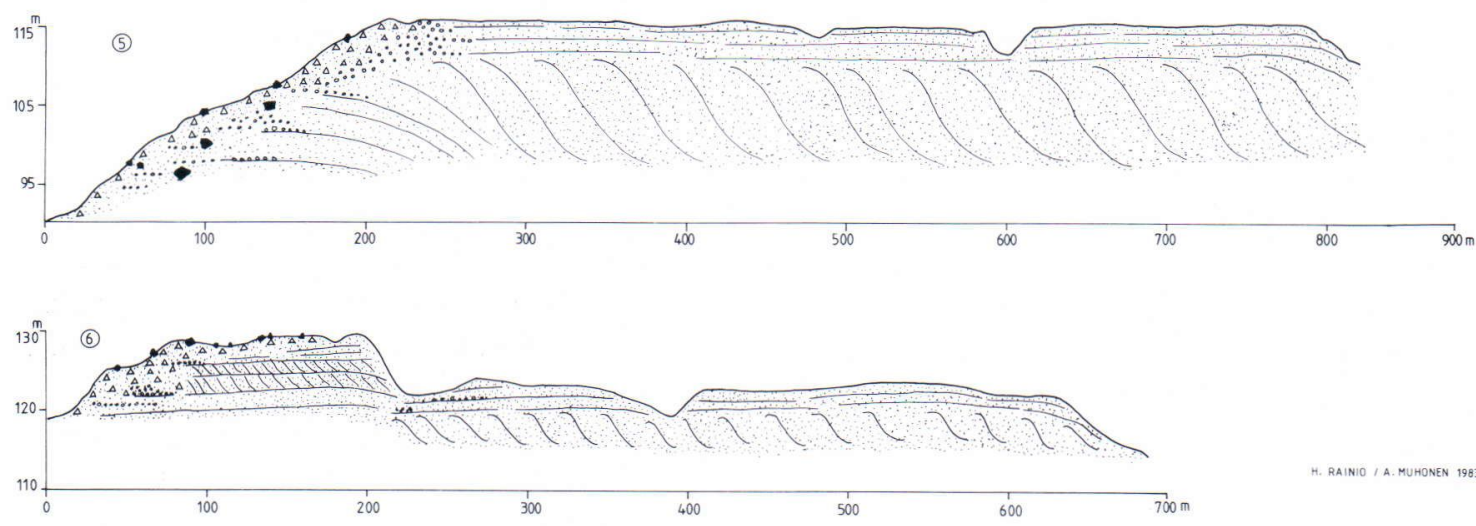

Fig. 2. Cross-sections of the Tuupovaara End Moraine. The internal structures are inferred. The sketch map also shows the eastern limit of the quartzite and mica shist area as well as the stone count places. 
an elevation of 185 meters, or ten meters above the level of the lake.

At its north end, the end moraine runs as a cluster of disconnected and small till ridges via the northwest side of Perttivaara to the vicinity of Haapovaara, after which it no longer continues as a clearly demonstrable feature.

The structure of the Tuupovaara End Moraine is in general typical: glaciofluvial deltas, with kettle holes and a mantle of till on the proximal side, or push-moraines and other till ridges clearly distinguishable from the distal-side terrain. The Kankaankylä ridge is an exception. It resembles in form a longitudinal esker or transverse till ridge. On the evidence of small gravel pits, it is composed largely of glaciofluvial material. On the proximal slope and even the summit of the ridge, however, there occurs till, and the northern delta plain of Pekkula is unmistakably an icemarginal formation.

The Tuupovaara End Moraine runs the closer to Salpausselkä II (Rainio 1972), the farther north one goes. The delta of Pykälävaara is located about 22 kilometers from Salpausselkä II, the delta plain of Kuljunniemi 17 kilometers and the north end of the Herajärvi section no more than 12 or 13 kilometers. The distance of the Patsola delta of Salpausselkä I from Salpausselkä II is about $25 \mathrm{~km}$, and that of the deltas of Musko and Kaurila between 23 and 24 kilometers.

\section{Movements of the Ice Sheet}

Striae observations indicate that the last movement of the continental ice sheet was almost westerly or slightly west-northwesterly during the formation of the Tuupovaara End Moraine (Fig. 2). The advance of the ice was thus perpendicular to the end moraine. This movement extended even beyond the moraine. Right on the distal side of the south- ern part of the formation, striae trending $290-295^{\circ}$ are to be seen ten or so kilometers away. To the southeast from Loitimojärvi, they extend for a distance of some four kilometers on the distal side up to the western margin of the esker complex of Otmen. North of Tuupovaara, no distinctly westerly striations are met with on the distal side of the end moraine. With the exception of these westerly striae, northwesterly or north-northwesterly striae predominate on the distal side.

The stone counts have been arranged in the accompanying drawing (Fig. 3) in an order determined by the distance measured from the border of the Karelidies in the direction of the ice flow.

The boundary between the Karelidic schists and the basement gneiss complex running NNW is at a distance of from two to sixteen kilometers from the Tuupovaara End Moraine between Pykälävaara and Tuupovaara (Fig. 2). Measured in line with the final movement of the ice sheet, the distance is slightly longer. When interpreting the directions of movement and transport of the ice sheet on the basis of stone counts, the amount of Karelidic quartzites and mica schists is therefore important.

The proportion of mica schists and quartzites decreases rapidly with increasing transport distance. After four kilometers, their share amounts to less than $10 \%$, after six kilometers less than $5 \%$ - generally, only between 1 and $2 \%$. On the delta plain of Hukkala, which is part of the end moraine, at a transport distance of not less than six kilometers, mica schist and quartzite each account for six per cent of the total count, the corresponding proportions on the marginal delta plain of Kuljunniemi, at a transport distance of $18 \mathrm{~km}$, being two and seven per cent, respectively, and on the deltas of Murtojärvenkangas and Mustalampi altogether $1.5 \%$ each. Close to Tuupovaara, on 


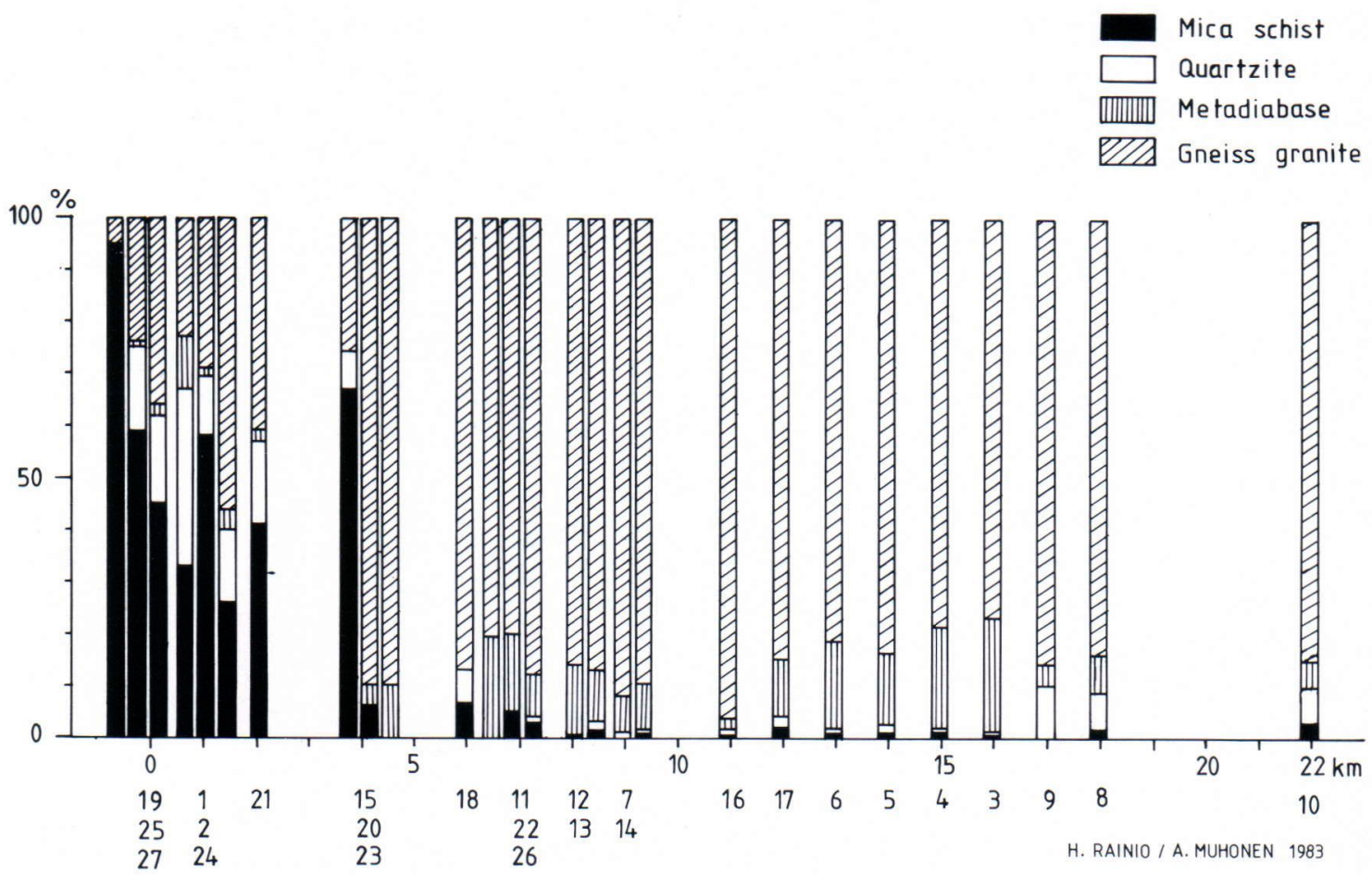

Fig. 3. Stone counts. In the $\mathrm{x}$-axis is shown the distance of the eastern limit of the quartzite and mica shist area. The numbers refer to observation points on the sketch map in fig. 2.

the distal side of the end moraine, the proportion of quartzite is rather large in two stone courts. The presence of quartzite there and at Kuljunniemi may well be due to some quartzite occurrence not marked on the petrographic map.

\section{Discussion and conclusions}

The nature of the Tuupovaara formation as an end moraine is clearly evident structurally as well as from the circumstance that the striations left by the last movement of the continental ice sheet run at right angle to it.

At its southern end, which was within the sphere of the Baltic Ice Lake, the moraine consists largely of glaciofluvial material. Parts of the formation are ridges and other parts delta plains. The marginal deltas lie at elevations of between 110 and 115 meters, or approximately on the B I level. This portion terminates in the marginal delta of Murtojärvenkangas. In the supra-aquatic area on the NNE side of Murtojärvenkangas the formation is made up of till ridges and mounds.

The present discharge channel of the waters of the surroundings of Loitimojärvi, the Jänisjoki valley, laid underneath the ice sheet at the time of formation of the Tuupovaara End Moraine. On the east side of Loitimojärvi, there apparently existed an ice lake, the surface of which, judging by the heights of the Mustalampi and Kuljunniemi deltas and the nearby esker plateaus, was at an elevation of about 130 meters, or roughly 15 meters above the level of the Baltic Ice Lake. 
The parts of the ice-marginal formation within the sphere of the lake are composed to a large extent of glaciofluvial material, on the proximal side of which runs a till ridge.

On the northeastern side of the village of Tuupovaara, the ice-marginal formation runs mainly through a supra-aquatic area. It is made up almost totally of till. This section reaches its greatest magnitude in the environs of Herajärvi, where a small ice lake once existed, judging by the esker plain situated on the immediate distal side of the end moraine. There are grounds for supposing that, in addition to till, the moraine contains abundant glaciofluvial material at the site of the former ice lake.

The parts of the end moraine formed within the influence of the Baltic Ice Lake and the ice lakes of Loitimo and Herajärvi are distinctly larger than the marginal formations located in the supra-aquatic area. The icemarginal formations of the Baltic Ice Lake and the ice lake of Loitimo consist mainly of glaciofluvial material.

The last westerly movement of the ice sheet described by Repo extended in the southern section of the study area between 20 and 30 kilometers to the distal side of Salpausselkä II, or as far as the esker complex of Otmen. The stone counts only indicate that material was transported from between west and northwest. Local rocks become predominant after a transport distance of a few kilometers.

The esker complex of Otmen appears to be an interlobate formation. It is located at the boundary between striations running in two different directions, and it includes portions constituting longitudinal eskers and icemarginal forms.
The southern starting point of the Tuupovaara End Moraine, the delta plain of Pykälävaara, lies 4-6 kilometers behind the line of the glacier margin represented by the plateaus of Salpausselkä I. The ridge of Kankaankylä is situated yet a kilometer farther past it. Also the trend of the striae of the Pykälävaara and Patsola districts indicates that the delta plain of Pykälävaara is slightly younger than the one at Patsola.

The elevations of the ice-marginal deltas created in the sphere of the Baltic Ice Lake do not deviate from the elevations of the plateaus of Salpausselkä I, which means that the Tuupovaara End Moraine cannot be much younger than Salpausselkä I.

The trend of the Tuupovaara End Moraine and its relation to Salpausselkä I indicate that the glacier margin did not, at least at the time of formation of the northeastern plateaus of Salpausselkä I, continue to the ice-marginal formations between Kiihtelysvaara and Selkäkangas, in the parish of Ilomantsi, as Hirvas and Ignatius et al. have propounded.

The fact that at its northern end the Tuupovaara End Moraine lies some ten kilometers closer to Salpausselkä II than at its southern end indicates that the margin of the ice sheet receded more rapidly in the Ilomantsi area than elsewhere.

Acknowledgments. The author is indebted to Dr. Hannu Hyvärinen for critically reading the manuscript and to Paul Sjöblom, M. A., for translating the manuscript from Finnish to English. My warm thanks are also extended to Mrs. Airi Muhonen for drawing the maps and graphs and to Mr. Timo Ruohomäki and Mr. Heikki Karvonen for their valuable help in collecting and arranging the material. 


\section{References}

Frosterus, Benj. \& Wilkman, W. W., 1917. Maalajikartan selitys. Lehti D 3 Joensuu. Suomen geologinen kartta 1: $400000.153 \mathrm{p}$.

Hirvas, Heikki, 1980. Moreenistratigrafiasta ja sen merkityksestä malminetsinnässä. Geologi 32 , $33-37$.

Ignatius, Heikki, Korpela, Kauko \& Kujansuu, Raimo, 1980. The deglaciation of Finland after 10,000 B. P. Boreas 9, 217-228. Oslo.

Leiviskä, Iivari, 1920. Der Salpausselkä. Fennia $41,3,1-388$.

Nykänen, Osmo, 1971. On the Karelides in the Tohmajärvi area, eastern Finland. Bull. Geol. Soc. Finland 43, 93-108.

Rainio, Heikki, 1972. Ennakkotiedonanto PohjoisKarjalan itäosan reunamuodostumista. Geologi $24,50-51$.

-, 1978. Exkursionslokaliteterna i Nordkarelen, 1-24. In: Norqua-exkursionen i södra och mellersta Finland 22-25. 5. 1978. Guide. Geological Survey of Finland. Espoo. Unpublished report P 13.7.004.

-, 1980. Pohjois-Karjalan kvartäärigeologiasta, 1-14. Helsingin yliopiston geologian ja paleon- tologian osaston opintoretkeilyn opas. Geological Survey of Finland. Quaternary department. Unpublished report P. 13.7.006.

-, 1982. Pohjois-Karjalassa ovat Suomen laajimmat pölyhietamaat eli lössit. Pohjois-Karjalan Luonto $12,32-34$.

Ramsay, Wilhelm, 1891. Uber den Salpausselkä im östlichen Finland. Fennia 4: 2, 1-8.

Repo, Reino, 1957. Untersuchungen über die Bewegungen des Inlandeises in Nordkarelien. Geol. Surv. Finland, Bull. 179. 1-178.

Repo, Reino \& Tynni, Risto, 1967. Zur spät- und postglazialen Entwicklung im Ostteil des ersten Salpausselkä. Bull. Geol. Soc. Finland 39, 133-159.

Rosberg, Johan E., 1899. Ytbildningar i Karelen med särskild hänsyn till ändmoränerna. Fennia 14, 7, 1-71.

Salminen, Reijo, 1980. On the geochemistry of copper in the Quaternary deposits in the Kiihtelysvaara area, North Karelia, Finland. Geol. Surv. Finland, Bull. 309, 1-48.

Manuscript received, January 10, 1983 